\title{
ANTHROPOLOGICAL DIMENSIONS OF THE MODERN MUSICAL ART OF EASTERN EUROPE
}

\author{
Olena Vereshchahina-Biliavska \\ Vinnytsia Mykhailo Kotsiubynskyi State Pedagogical University, Ukraine \\ Nataliia Mozgalova \\ Vinnytsia Mykhailo Kotsiubynskyi State Pedagogical University, Ukraine \\ Iryna Baranovska \\ Vinnytsia Mykhailo Kotsiubynskyi State Pedagogical University, Ukraine \\ Yuliia Moskvichova \\ Vinnytsia Mykhailo Kotsiubynskyi State Pedagogical University, Ukraine \\ Olesia Cherkashina \\ Vinnytsia Mykhailo Kotsiubynskyi State Pedagogical University, Ukraine
}

\begin{abstract}
The peculiarities of the world model and the human model in the Eastern European music art of the postmodern era were revealed. The research is based on a hermeneutical analysis of the contemporary Russian and Ukrainian composers' works. The research method builds on the systematic and historical approaches. It allows to consider the individual musical text as a subsystem of a higher order system. The sociocultural context was considered. The scientific novelty consists in revealing the specifics of the Eastern European artists' worldview of the last third of the XX and beginning of the XXI centuries. It is the consequence of studying their creativity in an anthropological dimension. The anthropological essence of the music of contemporary Ukrainian and Russian composers lies in a certain inconsistent polarity. The polarity is represented by the ironic and fragmented worldview combined with the religious quest. The awareness of the chaos and apocalyptic culture is combined with the religious support in its various manifestations. Therefore, the character in modern music has a dual essence. He is both marginal and a personality with strong spiritual support. In the works of contemporary Russian and Ukrainian composers, two postmodern worldview poles are organically combined: a destructive worldview and a desire for harmony. This polarity is caused by the crisis mentality of the modern post-totalitarian society.
\end{abstract}

Keywords: postmodernism, polystylistics, monostylistics, religiosity, spiritual genres, meditation.

\section{Introduction}

The music of the second half of the XX - the first decades of the XXI century is characterized by a wide conceptual, genre and stylistic spectrum, generated by postmodern consciousness. Expanding the boundaries of individual 
national schools, intensifying integration processes in artistic culture, rethinking the heritage of the past are far from a complete list of changes in the contemporary art. A variety of artistic worldviews and ways of embodying them in musical art was generated because of these changes. The critical attitude to cultural authorities led to a peculiar mockery of the tradition. It was manifested in the polystylistic technique. The desire to create "here and now" and forcing a listener or viewer to become a participant in creating an artistic text led to the emergence of the art of happening. An attempt to comprehend deeply the global problems of a human being gave rise to a new type of monostylistics and immersion in the genre sphere of sacred music of different religious traditions.

At present, musicology is actively exploring contemporary music art from the standpoint of transformation of the genre system, new principles of style formation, applying the latest compositional techniques. Creativity of wellknown composers of different national schools is constantly in the focus of researchers' scientific interests. However, the embodiment of the world and human models in the musical text remains unexplained in the works of researchers. According to the authors of the article, the artist's awareness of the world order and his place in it is one of the most important outcomes for the recipient in the process of artistic communication. This is because the average listener is not concerned with the problems of genre and style analysis or the peculiarities of the composer's technique, but he must understand the author's idea, his vision of the world and a person in it. Therefore, studying the anthropological aspects of musical works and an awareness of the specificity of embodying the world model and human model in the artistic texts of postmodern culture by the means of musical expression are relevant issues.

Studying the musical works of those authors, whose creativity was initially regulated by the ideological norms of the Soviet Union and the principles of "socialistic realism" and then liberated from the yoke of the communist regime, is a separate aspect of the described approach. In particular, the music of Russian and Ukrainian composers shows the specifics of artistic processes in the post-Soviet space, marked by social catastrophes and mental shifts. The purpose of the study is to find out the content of the world model and human model inherent in contemporary music in the territory of Eastern Europe based on a hermeneutical analysis of the Russian and Ukrainian composers' works of the last third of the XX - the first decades of the XXI century. This goal allowed us to formulate the objectives of the article: characterization of the world and human models in the Western European music of the postmodern era; hermeneutical analysis of Russian and Ukrainian composers' works; identification of key ideological traits of post-Soviet music and their comparative analysis with artistic concepts of Western European art. 
SOCIETY. INTEGRATION. EDUCATION

Proceedings of the International Scientific Conference. Volume IV, May $28^{\text {th }}-29^{\text {th }}$, 2021. 716-726

\section{Literature Review}

There is no shortage of music studies exploring the creativity of contemporary composers in Eastern Europe. In particular, there are some monographs and scientific studies, which are devoted to the music of A. Schnittke, that became a landmark for studying the course of musical processes in the post-Soviet space. The issues of using ancient genre models by the composer are revealed in the research of V. Kholopova (Kholopova, 2003) and E. Akishina (Akishina, 2003). Belge (Belge, 2018) focuses attention on studying the specifics of choral and symphonic music, considering the penetration into it of pop stylistic features. The problems of interpretation the peculiarities of Christian subjects and functioning of genres of sacred music in the works of A. Schnittke are presented in the studies of A. Kuznetsova and E. Kaishauri (Kuznetsova, Kaishauri, 2019), in the dissertations by J. Lehmann (Lehmann, 2018) and M. Jennings (Jennings, 2002), works of I. Moody (Moody, 2004; 2018), K. Sander (Sander, 2017), K. Segall (Segall, 2013).

The peculiarities of embodying the traditions of sacred music in the works of contemporary Ukrainian artists are studied by the Ukrainian researcher and composer O. Kozarenko (Kozarenko, 2001). He repeatedly referred to the genres and style canons of Christian music in his compositions. The interest of Ukrainian composers to the spiritual genres prompted I. Gulesko's life and research (Gulesko, 2002).

The cultural approach to the study of the Russian and Ukrainian composers' works in the last third of the XX - early XIX centuries is shown by P. Schmelz (Schmelz, 2009), who explored the special situation of the music functioning during the late Soviet and early post-Soviet eras. The creative activity of Andrei Volkonsky, Alfred Schnittke, Arvo Pärt, Sophia Gubaidulina, Valentin Silvestrov and others was in a focus of his attention.

M. Chizmich (Chizmich, 2011) explores the music of Eastern European composers in the last third of XX century in a sociocultural context. M. Chizmich uses analytical methods of psychology, sociology, literary criticism and cultural studies. She presents series of essays in which she identifies the ways methods of reflection of composers and listeners on issues of historical trauma and loss from the positions of hermeneutical analysis. Analyzing typical postmodern techniques (including quotation, fragmentation), the researcher finds musical analogies with the psychological and emotional reactions of postSoviet society to trauma and grief. M. Chizmich argues that music can help people to understand their emotions, interpret memories and create a sense of collective identity. Her focusing on the music of the 1970-80s is explained by the fact that this period was marked by a rethinking of the events and consequences of World War II and the era of Stalin's rule. The works of Alfred 
Schnittke, Galina Ustwolskaya, Arvo Pärt and Henryk Goretsky were the objects of analysis. In this works, according to M. Chizmich, the basic techniques that embody, the typical reflections of post-communist society, were clarified. However, the researcher focuses solely on the compensatory and reflexive functions of the music of these composers.

A general overview of the problems of music in the post-Soviet space was also provided by V. Adamenko (Adamenko, 2007) in the study of the complex phenomenon of neo-mythologism in music inherent in totalitarian regimes. The strength of this work is an interdisciplinary approach that brings together various aspects of many fields of culture (music, mythology, semiotics, philosophy, religion, anthropology)

The authors of the article offer their own "inside" look at the music of the period as they themselves represent the post-Soviet culture. At a certain, albeit short, historical distance, we will attempt to determine the meaningful content of the music of Russian and Ukrainian composers from anthropological positions of embodying the image of the world and the image of a contemporary in it.

\section{Discussion}

In the study of musical texts, the authors rely on the principles of hermeneutical analysis, which allows getting into the essence of the content of the artistic text. Using a systematic approach makes it possible to consider a separate musical text as a subsystem of a higher order system such as contemporary creativity of the Eastern European composers. The authors of the article also rely on the position of the historical approach in their study of composer creativity, because each specific musical sample should be considered in a certain sociocultural plane.

The article was based on works of Russian and Ukrainian avant-garde composers whose creativity came from the 1960s and 1970s and developed during the period of active destruction of the established Soviet-colonial system. A preliminary hermeneutical analysis of the works of Russian and Ukrainian composers including A. Schnittke, S. Gubaidulina, E. Denisov, A. Karamanov, F. Karaev, B. Buevsky, E. Stankovych, O. Kozarenko, L. Dychko, V. Zolotukhin, V. Runchak, L. Grabovsky, V. Sylvestrov, S. Zajitko and others was conducted.

For an understanding of the anthropological specifics of the Eastern European music, the main features of the Western European artistic worldview should be highlighted. Postmodernism as a spiritual phenomenon of the second half of the twentieth century is characterized by self-awareness of the crisis perception of reality, which gives rise to feelings of despair, confusion, and exhaustion of being. The Western version of postmodernism embodies the rupture of social and spiritual bonds of life and losing moral orientations. 
Disharmony and destruction are the main features of the postmodern artistic worldview that sees the world as horrifying and bizarre. The lack of integrity of the world is manifested in the chaos, fragmentation, and collage of musical art. The attempt to comprehend the world is made by artists in terms of vision of past eras and the cultural experience of mankind. In postmodern music, this is reflected outwardly in the combination of contrasting style elements and quotations from other periods of art. This brings to the music a certain chaos that reflects the chaos and the absurdness of the world and an attempt to realize it. A certain contradiction of the artistic text, which is the embodiment of the contradiction of the world, has caused a variety of its interpretations.

A person in such a culture is largely a marginal being at the crossroads of different eras, whose nature is determined by the crisis of being. This causes the particular emotional vulnerability, irony and skepticism of the postmodern personality. The worldview of the hero of an artistic text can often be expressed by the phrase "a strange viewpoint of a strange person in a strange world".

The mythology often prevails in the postmodern worldview rising to the philosophical level. The didactic task of myth is to realize the individual in the Universal's aspect in the context of eternity. However, mythmaking in the Western European version often relies on postmodern irony, while in the Eastern European art, mythmaking is perceived as an ideological norm.

The Western European postmodern world model is characterized by disharmony, whimsy, introversion, and lack of integrity. The model of the marginalized person in this worldview system is characterized by irony, skepticism, awareness of the absurdity of being. According to such a worldview, art often appeals to the unconscious, seeks to destroy canons, and use collage, that leads to fragmentation and chaos of artistic texts. The multilingualism of styles and techniques is the main complexity of interpreting, but it creates a new versatility and leads to a variety of interpretations.

Among the favorite topics of Western European postmodernism, there is a desire for an awareness of the non-European East worldview and the embodiment of the Christian theme. The attraction to spiritual subjects is also typical for the music of the late O. Messiaen. These two topics later found their versatile embodiment in the works of Russian and Ukrainian composers (A. Schnittke, S. Gubaidulina, E. Denisov, V. Martinov, V. Sylvestrov, E. Stankovych, M. Shukh, L. Dychko, A. Karamanov and many others).

What kind of world model does Eastern European art in the conditions of early postmodernism, which coincides in time with The Khrushchev Thaw and The Era of Stagnation, reflect? In 1960-1970, Soviet art still was laced with ideological and stylistic norms of the pseudo-method of "socialistic realism". It continued to reflect and manipulate the perception of the victims of World War II, the great victory of the Soviet people led by the Communist Party, the 
debunking of fascism as the world evil, the construction of a "bright communistic future”. The ideologically grounded works of the official Soviet composers are clearly structured for good and evil, true and false. The creativity of the composers of the so-called "Russian trinity", which includes A. Schnittke, E. Denisov, and S. Gubaidulina, declared itself at the turn of the late 1960s. They demonstrated that anthropological principles of the postmodern artistic worldview also penetrate totalitarian culture. It is well known that the First Symphony (1969-1972) by A. Schnittke was a manifestation of polystylistics in Russian music of The Era of Stagnation. According to the authors of the article, it also acts as a manifesto of the postmodern worldview in the territory of the Soviet empire. There is the picture of the world appearing not to be holistic and ideologically structured, but fragmentary, chaotic, and presented through the prism of an ironic and skeptical worldview. If collage in the West was already a common technique, then in Soviet music we see the first consistent and semantically justified use of it. For A. Schnittke, the deliberate use of banal thematicism was not new at the time, because in Serenade for Five Instruments (1968) he extensively used the intonation of musical life, bringing to the theme of composition the melody of variety songs, jazz, dance (polka, waltz, foxtrot). Similar are the finals of both cycles, where the combination of serious and everyday music makes it possible to realize the loss of the high art exemplars of the artistic essence in contemporary society. The overall story of the First Symphony, formulated by its author, is the struggle of harmony and disharmony, in which it is important to find true and meaningful harmony. The composer resorted to the hypertrophied image of the domestic sphere and leveling of the value of high art to reveal such a "plot". The postmodern vision of the absurdity and chaos of the world is vividly embodied in the second part of the cycle filled with stylizations, allusions, quasi-quotations of non-original styles of household music. Such an image of the world shows us the opposition to the official art of thinking of a young Soviet-era artist. It is supported by the images and stylistics of the Second Sonata for Violin and Piano (1967) and Concerto Grosso No. 1 (1977). Pessimism and the devaluation of ideals sound in the Concerto for Viola and Orchestra (1986), in which A. Schnittke already uses monostylistics of a new type, built on the subtle allusions of romantic music.

A. Schnittke's music was a single manifestation of the postmodern worldview tendencies, but the ideological ideas of postmodernism were fully embodied with the fall of the Soviet empire in the countries formed on its wreckage. The works of E. Denisov, S. Gubaidulina, F. Karaev, B. Tyshchenko and many other artists are a confirmation of this. There are some examples below.

Russian-Azerbaijani composer Faraj Kara ogli Karaev embodied the ironic and fragmented worldview in the composition "Ist Es Genug?" ("Is That's 
Enough?”, 1993), saturated with allusions and hints. In "Der Stand der Dinge” ("The State of Things", 1991), the composer embodied the chaotic thinking of the post-Soviet man, his pessimism, and a sense of hopelessness through the play of styles.

Irony, skepticism, and fragmentation of the worldview came into the entirety of Eastern European music precisely in the post-totalitarian period. It was the time when the Soviet ideological system was destroyed. The personality prone to deep reflection felt the destruction of established worldview dogmas with extreme severity.

Besides embodying a fragmented and chaotic vision of the present, an appeal to religious subjects was a one more striking feature of post-Soviet music. It was manifested in two aspects: 1) appeal to the ancient genres of different Christian denominations; 2) interest in Eastern religions, inseparable from Eastern systems of worldview and meditation. A. Schnittke again was one of the first to embody this tendency. He restored the genre model of Catholic Mass in his Symphony No. 2 (1977), following the polystylistic mockery of tradition in the First Symphony. The composer resorted to quoting a Latin gradual melody at the beginning of each section in the cycle.

A. Schnittke's creativity is characterized by a versatile worldview, also inherent in the postmodern art. This is manifested not only in the wide stylistic amplitude but also in its appeal to the genres of the various Christian denominations. His String Quartet No. 2 (1980) is based on the melodic material of iconic chants. Symphony No. 4 (1984) is imbued with the spirit of ecumenism and contains themes of Judaic, Catholic, Orthodox and Protestant origin. Particular attention should be paid to the fact that all these works appeared in the period of Soviet ideological rule and did not coincide with the official art of the empire. At the same time, they are evidence that part of the Soviet artists worked in postmodern tendencies, as if prophesying the subsequent cataclysms of the communist regime and seeking ways to compensate the psychological stress from destroying the norms familiar to the Soviet man.

A. Schnittke was not alone in his ideological and stylistic pursuits. In particular, "Requiem" (1980) by E. Denisov also embodies the concept in line with typical postmodern reflections on the problem of the perishability of human existence and the lack of integrity of the Universe. The combination of Oriental mysticism and religious thinking is typical for S. Guibaydulina's creativity. This thesis is corroborated by the works of different compositions: "Rubaijat", cantata for baryton and chamber ensemble (1969); "In croce" for cello and organ (1979); "John’s Passion" (2000) and "Easter for John" (2001), both for soloists, choir and orchestra; "Sonnengesang" for cello and ensemble (1997); "Waiting" for accordion (1986); cantata "From Chasoslov" (1991) and others. 
Postmodern ideas of fragmentation, irony, provocativeness, and destructiveness are most clearly reflected in the works of Ukrainian composers Volodymyr Runchak and Sergey Zajitko. In their compositions, the typical worldview features of postmodernism are fully revealed. The desire for postmodern meditation is explicit in the works of Alemdar Karmanov, Oleksandr Shchetynsky, Mikhail Shukh and many other artists.

However, Boris Buevsky with his First Symphony (1965) and Yevhen Stankovych with his Symphony "In modo collage" (1971) were the first Ukrainian composers to show a fragmentary, kaleidoscopic and ironic beginning in the form of "playing with styles" in their music. The distorted world, which depends on the interpreter and the recipient, appears in the series "Songs of the Nations" by S. Zajitko. The creativity of this composer is, perhaps, the most provocative among contemporary Ukrainian artists ("Phalasiped", "Here it is!", "Playing ball”, "Epitaph of the Marquis de Sad”, "Bad music").

The postmodern worldview is fully embodied in the works of V. Zolotukhin, V. Runchak, L. Grabovsky, V. Sylvestrov. It was proved by the hermeneutical analysis, which appeared in the period of independent Ukraine. Unlike in the western version, this worldview is embodied with a delay of 30-40 years in the works of most Eastern European composers.

The so-called "new religiosity" spread throughout the culture of the last third of the XX and beginning of the XXI centuries is widely embodied in the contemporary post-Soviet music. It combines the appeal to religious subjects, the restoration of ancient genre models of sacred music and the attraction to oriental meditation. The contradictory picture of the world appears in many works by Alemdar Karamanov (in particular, the cycles of symphonies "Sovershyshasia" (1965-1966) and "Byst" (1976-1980), where Christian apocalyptic motives and an oriental sense of the harmony were combined). It should be noted that $\mathrm{A}$. Karamanov began turning to religious subjects in the early period of his creative activity while living in Moscow, where he became one of the bright leaders of the musical avant-garde.

There are compositions of many other authors related to the current of "new religiosity": Lesia Dychko ("Liturgy”, 1989-2002); Igor Shcherbakov ("Repentance Verse" for violin and string orchestra (1989), chamber symphonies “ARIA-PASSIONE” (1992, 2000), cantata “Stabat Mater” (1992), “Agnus Dei” (1996), "Orthodox Choir Concert in Memory of S. Rachmaninov" (1996), "Theotokos, Virgin, Rejoice" (1998), musical and stage performance "Jesus" (Prologue, 1998)); Volodymyr Runchak ("Kyrie eleison” (1990), "On the Death of Jesus", "Prayer" (1993), Chamber Symphony "Spiritual Songs" (1988), "Requiem” (1990)); Alexander Kozarenko ("The Time of Repentance” (1998), Chacon for the Symphony Orchestra (1990) and Pasakali on the Galician theme for organ (1989), “Irmologion” for string instruments (1988)) and many others. 
It can also be stated that in the works of contemporary Ukrainian composers, two postmodern worldview poles are organically combined: a destructive worldview and a desire for harmony.

\section{Results of the Research}

In a result of our reflections on the embodiment of the world model and the human model in the works of Russian and Ukrainian composers as representatives of Eastern European artistic thinking, we can not only correct, but sometimes oppose the judgments of Western scholars of contemporary music. P. Schmelz (Schmelz, 2009) in his research puts forward the thesis that the works of A. Volkonsky, A. Schnittke, A. Pärt, S. Gubaidulina, V. Silvestrov and other composers, who were in the forefront of Soviet art of 1960-1980, are not quite "Soviet" but not "anti-Soviet" and embodies the double relations of citizens of that time with themselves and the state. The authors of the article are inclined to believe that the music of these composers embodies not so much double relations as the world-model and model of a person belonging to the intellectual elite of Soviet society. P. Schmelz also considers A. Schnittke's First Symphony as one of the "markers" of The Khrushchev Thaw. The team of authors only partially agrees with this statement. The hermeneutical analysis of the symphonic cycle leads to the conclusion that the First Symphony was one of the first works in the Soviet space in which the synergistic conception of the world and the image of a person is comprehensively embodied.

P. Schmeltz also argues that the so-called "softening" of Soviet avant-garde music as the end of its "unofficial" period in the mid-1970s is associated with the end of the "musical thaw". Such a hypothesis also seems doubtful to us. It is more appropriate to associate this tendency with the "post-guard syndrome". It is often manifested in a new orientation to tradition, an aspiration for simplicity and clarity, a revival of old musical genres and forms in a new historical situation.

The authors of the article are impressed by the systematic approach to the analysis of contemporary music art, proposed by V. Adamenko (Adamenko, 2007), which explores the phenomenon of neo-mythologism in music. However, we do not consider neo-mythologism solely a tendency, but rather a mental component embodied in works of different stylistic directions, including polystylistic compositions. We fully agree with V. Adamenko's assertion that the technique of polystylistics is an attribute of neo-mythologism in music. 


\section{Conclusion}

Because of the hermeneutical analysis of the Russian and Ukrainian composers' works of the last third of the XX - beginning of the XXI centuries, we can conclude that the anthropological concept of the Eastern European contemporary music consists in the desire to combine the incompatible. Developing in the realm of postmodernism, the creativity of Ukrainian and Russian artists, on the one hand, embodies the typical principles of postmodernism in its own way, and on the other, shows the specifics of artistic thinking in post-totalitarian culture. Polystylistics, variously embodied in the works of many artists, not only demonstrates the gaming essence of the contemporary art and the fragmented vision of the world model. It is also capable of embodying the polarity of thinking: an awareness of the chaos and apocalyptic culture, on the one hand, and an attempt to find support in religion, on the other. Therefore, the hero in modern music has a dual essence: he is both marginal and a personality with strong spiritual support. According to the authors of the article, such polarity is a consequence of the crisis mentality of the modern post-totalitarian society, which is still painfully recovering from the consequences of Soviet colonialism, but is not always clearly aware of the vector of its future development. The artists found themselves at the crossroads of modern culture in a state of permanent creative quest. And this quest will continue to arouse the keen interest of cultural scientists and art critics.

\section{References}

Adamenko, V. (2007). Neo-Mythologism in Music: From Scriabin and Schoenberg to Schnittke and Crumb. Edition: NED - New edition Published by: Boydell \& Brewer, Pendragon Press

Akishina, E. (2003). Semantic aspects of A. Shnittke's analysis of creativity. Candidate's thesis. Moscow: MGK.

Belge, B., Between, E. and U. (2018). Alfred Schnittke, Popular Culture and Serious Music in Late Soviet Socialism. Euxeinos, 8(25-26), 107-116.

Chizmich, M. (2011). Performing Pain: Music and Trauma in Eastern Europe. Oxford University Press.

Gulesko, I. (2002). Musical-artistic typology of the requiem in the European context. Kharkiv - Melitopol: Sana.

Jennings, M. D. (2002). Alfred Schnittke's Concerto for Choir: Musical Analysis and Historical Perspectives. Doctoral dissertation, Florida State University.

Kholopova, V. (2003). Composer Alfred Shnittke. Moscow: Arkaim.

Kozarenko, O. (2001). Sacral creativity of Ukrainian composers of the twentieth century in the context of national musical-semiotic processes. Ukrainian musicology (sciencemethodology), 30, 138-146.

Kuznetsova, A., Kaishauri, E. (2019). Spiritual and biblical themes in the works of A. Shnittke. The science. Art. Culture, 8(23), 106-114. 
Proceedings of the International Scientific Conference. Volume IV, May $28^{\text {th }}-29^{\text {th }}$, 2021. 716-726

Lehmann, Zh. (2018). Alfred Shnittke's quest for a universal musical language in the penitential psalms (1987-88). Dissertation. Submitted in partial fulfillment of the requirements for the degree of Doctor of Musical Arts in Music with a concentration in Choral Music in the Graduate College of the University of Illinois at UrbanaChampaign Urbana, Illinois, 159.

Moody, I. (2018). An Outline of History of Russian Sacred Music. Retrieved from http://ivanmoody.co.uk/articles.russiansacredmusic.htm.

Moody, I. (2014). Modernism and Orthodox Spirituality in Contemporary Music. Joensuu: The International Society for Orthodox Church Music.

Sander, K. (2017). A New Musical Setting of the Divine Liturgy. In Orthodox Arts Journal, August 22. Retrieved from https//www.orthodoxartsjournal.org/a-new-musical-settingof-the-divineliturgy.

Segall, C. M. (2013). Triadic Music in Twentieth-Century Russia. Doctoral dissertation, City University of New York.

Schmelz, P. J. (2009). Such Freedom, if Only Musical: Unofficial Soviet Music during the Thaw. New York: Oxford University Press. 